Discussion Paper No. 606

\title{
ARE THE JAPANESE UNIQUE? AN ANALYSIS OF CONSUMPTION AND SAVING BEHAVIOR IN JAPAN
}

Charles Yuji Horioka

June 2004

Revised June 2004

The Institute of Social and Economic Research

Osaka University

6-1 Mihogaoka, Ibaraki, Osaka 567-0047, Japan 


\title{
ARE THE JAPANESE UNIQUE? AN ANALYSIS OF CONSUMPTION AND SAVING BEHAVIOR IN JAPAN* Charles Yuji Horioka
}

March 2003; revised January 2004, May 2004, June 2004

\begin{abstract}
In this paper, I conduct an analysis of consumption and saving behavior in Japan, looking both at trends over time and comparisons with the other industrialized countries. I find that some of the conventional wisdoms (that the Japanese are asset-rich and hold conservative portfolios) still hold but that others (that the Japanese are high savers and shun borrowing) no longer hold and that the Japanese are not unique, with the United States and the other Anglo-Saxon countries being the true exceptions in many respects.
\end{abstract}

Contact information: Charles Yuji Horioka, Institute of Social and Economic Research, Osaka University, 6-1, Mihogaoka, Ibaraki, Osaka 567-0047, JAPAN.

Telephone: 81-(0)6-6879-8586 (direct-dial), 8574 (to leave a message), facsimile: 81-(0)6-6878-2766, email: horioka@iser.osaka-u.ac.jp

*I am grateful to Takatsugu Akaishi, Sheldon Garon, Patricia Maclachlan, Sven Steinmo, and the other participants of the two conferences on "Consumer Culture and Its Discontents" and to Shizuka Sekita, Midori Wakabayashi, and the other participants of my graduate seminar for their invaluable comments and insights and to the Ministry of Education, Culture, Sports, Science, and Technology of the Japanese Government for Grant-in-Aid for Scientific Research number 12124207. 
Japanese people often trumpet their putatively "unique" characteristics vis-à-vis other nations. This is particularly evident with respect to their saving and consumption behavior. According to various public opinion surveys, Japanese respondents overwhelmingly describe themselves as a people who love to save while exercising uncommon frugality in their consumption. ${ }^{1}$ By contrast, Western observers have generally criticized the Japanese for extolling such thriftiness and for saving too much and consuming too little. For example, in the early 1980's, when Japan was running record trade and current account surpluses, the United States and Japan's other trading partners urged the Japanese government to promote consumption rather than saving as a way of reducing those surpluses, and the so-called Maekawa Report (which stressed the need to make Japan into a more consumption-oriented society) was the Japanese government's response to such criticism. The conventional wisdom, whether Japanese or foreign, regards the Japanese as big savers who shun borrowing and hold unusually conservative portfolios; the only difference is whether this is regarded as a good thing or a bad thing.

This chapter marshals comparative data to examine whether Japanese saving and consumption is truly so distinctive. Although we commonly compare Japan to "the West," the Western countries themselves demonstrate considerable variation in their saving and consumption patterns. How then does the saving and consumption behavior of the Japanese compare to that of other industrialized countries (notably the other Group of Seven or G7 countries)? If Japan does resemble some of the Western countries, is it more similar to the Anglo-Saxon countries or to continental Europe? By exploring changes in saving and consumption behavior over time, this chapter also challenges the conventional view of Japanese thrift and frugality as static traits. 


\section{The Saving Behavior of the Japanese}

\section{Are the Japanese Big Savers?}

Do the Japanese save more than consumers in other countries? To answer this question, I examine trends over time within Japan, followed by an international comparison. I then seek to explain Japanese saving behavior in the past, present, and future.

(1) Trends over Time. As I have shown elsewhere, ${ }^{2}$ Japan's household saving rate was volatile during the prewar, wartime, and early postwar periods. Saving rates were low, sometimes even negative, during about half of the years in this period (1907-15, 1921-30, and 1946-49). However, saving rates were high and generally in the double digits, during the other years (1906, 1916-20, 1931-44, and 1950-54). Indeed, household saving rates exceeded 30 or even 40 percent at the height of World War II (1941-44), when goods were scarce or rationed and when the state encouraged and often forced people to save. Thus, there is no simple answer to the question of whether Japan's household saving rates were high or low from 1906 to 1954. Saving rates ranged from negative to astonishingly high levels.

Before we can assess saving rates in more recent decades, a methodological note is in

order. Scholars disagree in their interpretations of recent Japanese saving behavior, in part because the Japanese government switched from the United Nations' System of National Accounts 1968 (SNA68) to the U.N.'s System of National Accounts 1993 (SNA93) in 2002, as a result of which a continuous time series for the entire postwar period is unfortunately not available. Figure 1 shows National Accounts data on Japan's household saving rate based on both Systems of National Accounts for the 1955-2002 period. Data based on both Systems of National Accounts are available for the $1980-98$ period, and as can be seen from Figure 1, the two series were relatively close in 1980-94 (within 2.6 percentage points). However, the gap 
between the two series widened to 3.3 to 4.9 percentage points in 1995-98 (with the series based on SNA93 falling below the SNA68 series except in 1990-91). Moreover, trends in the household saving rate after 1991 differ greatly depending on which SNA we use. The SNA68 series leveled off in the 12.6 to 13.7 percent range during the $1991-98$ period, whereas the SNA93 series reveals a sharp decline from 13.3 percent in 1991 to 5.4 percent in 2002 . Which series are we to believe?

The biggest difference between the two series lies in the treatment of bad loans. The older SNA68 exaggerates the household saving rate for the following reason: under SNA68, write-offs of bad loans to households and unincorporated businesses are treated as a current transfer from financial institutions to households. Thus, bad loan write-offs increase the incomes of households, and since their consumption does not change, their saving appears to increase. By contrast, SNA93 treats write-offs of bad loans to households and unincorporated businesses as a decline in the asset holdings of financial institutions, and thus they do not affect the saving rates of households.

The leveling off of the SNA68 saving rate after 1991 primarily reflects the write-offs of bad loans to households and unincorporated businesses that financial institutions starting taking after the collapse of the bubble and is thus likely to be a temporary phenomenon. If no write-offs of bad loans had been taken during this period, the SNA68 series would no doubt have revealed the same sharp decline as the SNA93 series. I have much more faith in the series based on SNA93, and thus it appears that Japan's household saving rate declined steadily after 1991 and that it is no longer high by either absolute or relative standards. ${ }^{3}$

As Figure 1 shows, Japan's household saving rate was high (in the double digits) until the mid-1990s, peaking at 23.2 percent in 1974 and 1976 before declining sharply. It exceeded 20 percent during the $1973-78$ period, 15 percent during most of the 1961-86 period, and 10 
percent during the 1955-98 period (in the case of the series based on SNA68) and the 1955-95 period (in the case of the series based on SNA93). However, the more accurate SNA93 series has been in the single digits since 1996, falling to a paltry 5.4 percent in 2002 .

To sum up, Japan's household saving rates were high during most of the postwar period (1955-95), but they have been low since 1996.

(2) International Comparison. Cross-national comparisons of saving rates present even greater methodological challenges. Data on household saving rates are available for twenty-one of the Organization for Economic Cooperation and Development (OECD) member countries. However, for thirteen of these countries (including Japan), the data measure the net household saving rate, whereas for the other eight countries, they measure the gross household saving rate. The difference is significant. In the case of the net household saving rate, the numerator (household saving) and denominator (household disposable income) both exclude the depreciation (consumption of fixed capital) of households and unincorporated businesses whereas both the numerator and denominator of the gross household saving rate include depreciation. Thus, the two are not comparable, and the gross household saving rate will invariably be much higher than the net household saving rate. Because I wanted to compare the household saving rates of all OECD member countries for which data are available, I converted the gross household saving rate figures to a net basis by using a conversion factor of 0.7 (which is the approximate ratio of the average net household saving rate to the average gross household saving rate for the countries and years used in the present analysis).

My comparative data challenge the conventional view that the Japanese are uniquely thrifty and/or high savers for all times. Table 1 presents actual or estimated data on net household saving rates for the 1985-2002 period for the twenty-one OECD member countries for which data are available (Table 1A shows actual data on net and gross household saving 
rates for the same years and the same countries). The Japanese entered this period as notably, but not uniquely, high savers. As Table 1 shows, in 1985, Japan's household saving rate (16.5 percent) was second only to Italy (21.5 percent) among the OECD member countries for which data are available, followed closely by Canada (15.8 percent) and South Korea (14.8 percent). Thereafter, however, Japan's household saving rate fell sharply both in level and rank, from 16.5 percent in 1985 to 5.9 percent in $2002^{4}$ and from second in 1985 to fourth to sixth in 1990-2000 and to thirteenth in 2002 among the OCED countries for which data are available. When Japan's household saving rate is compared to the OECD mean, it was nearly twice as high in 1985 but slightly lower in 2002.

It is noteworthy that Japan has shared the distinction of being a big saver with a variety of nations in both Europe and East Asia. Among the OECD member countries for which data are available, the number one saver was Italy in 1985, South Korea (the only other East Asian member) in 1990, the Czech Republic in 1995 and 2000, and France in 2002. Other OECD members that have attained double-digit household saving rates at least once include Australia, Austria, Belgium, Canada, Germany, the Netherlands, and Spain. If we confine our comparison to the Group of Seven (G7) countries (Canada, France, Germany, Italy, Japan, the United Kingdom, and the United States), Japan was second only to Italy during the 1985-95 period but fell to third (a tie) behind France and Italy in 2000 and to fourth behind France, Italy, and Germany in 2002. Moreover, there are many non-OECD economies in Asia (such as China, Hong Kong, Singapore, and Taiwan) that appear to have higher household saving rates than Japan at present, notwithstanding the absence of comparable data.

In addition, the Japanese government appears to have overestimated Japan's household saving rate vis-à-vis other countries, with several conceptual differences and deficiencies in Japan's official data imparting an upward bias in the level of Japan's household 
saving rate. ${ }^{5}$

Although it is beyond the confines of this chapter, we should also note substantial variations in household saving rates among the Western nations. The OECD member countries with the lowest household saving rates (those not exceeding 10 percent during the 1985-2002 period) include Denmark, Finland, New Zealand, Norway, Portugal, Sweden, Switzerland, the United Kingdom, and notably the United States.

To sum up, the cross-national data challenge us to reevaluate our understanding of saving behavior in Japan and elsewhere. First, the Japanese were unquestionably big savers until the mid-1990s, but they were hardly unique and showed a household saving rate that was roughly comparable to that of several leading continental European nations as well as to that of South Korea, a country that has long emulated Japan's developmental policies. These data present a challenge to those who insist that the Japanese are uniquely thrifty or that East Asians are systematically more inclined to save than "Westerners."

Second, the data also reveal that the United States and the other Anglo-Saxon countries (in particular, New Zealand and the United Kingdom) are more of an exception than Japan, showing virtually the lowest household saving rates among the major industrialized countries.

Lastly, the data show that, in recent years, Japan's household saving rate has fallen far below that of Europe's leading savers and that it is converging to Anglo-Saxon levels, and I argue in section (4) below that it will decline even further in the future.

(3) Why Were the Japanese Big Savers? Elsewhere, I list more than thirty factors that have been invoked to explain Japan's high household saving rate during much of the postwar period. ${ }^{6}$ Here, I examine what I consider to be the nine most salient factors.

First, the high rate of income growth during the high-growth era from the 1950s to 
early 1970s undoubtedly helped raise Japan's household saving rate. When income grows too rapidly or unexpectedly, households often cannot adjust their living standards and consumption patterns at the same pace, and as a result, saving (the difference between income and consumption) tends to increase, at least temporarily.

Second, household asset holdings were very low in Japan just after the Second World War. The war destroyed much of Japan's housing stock, and the postwar hyperinflation reduced the real value of financial assets to almost nothing. Japanese households presumably saved as much as they did in part to restore their asset holdings to desired levels.

Third, consumer credit was not readily available in Japan until recently, as I will discuss later. As a result, Japanese households found it necessary to save in advance of major purchases such as purchases of housing, automobiles, furniture, and electrical appliances. Moreover, the paucity of credit also increased the need for precautionary saving because Japanese households knew that they would not be able to borrow in times of emergency.

Fourth, Japan's bonus system of compensation, whereby a large chunk of employee compensation is paid in the form of semiannual lump-sum bonuses, is often said to have encouraged or at least facilitated saving.

Fifth, the age structure of Japan's population was virtually the youngest among the industrialized countries until recently. As Table 2 shows, in 1975, the share of the elderly (those aged 65 or older) in Japan's total population was only 7.9 percent. Among the OECD member countries Japan ranked second to last behind South Korea at 3.6 percent. According to the life cycle hypothesis, the aggregate household saving rate will be higher in a country with a young population because the young typically work and save whereas the elderly typically retire from work and dissave. ${ }^{7}$

Sixth, the Japanese government introduced many tax breaks for saving such as the 
maruy $\bar{u}$ system (whereby the interest income on bank and postal deposits and on government bonds was tax-exempt, up to a limit). These tax breaks may have induced Japanese households to save more than they would have otherwise.

Seventh, public old-age pension benefits were relatively low in Japan until 1973. This made it necessary for Japanese households to save on their own to prepare for their life after retirement.

Eighth, the Japanese government and a quasi-governmental organization formerly called the Central Council for Savings Promotion engaged in a variety of saving promotion activities. Sheldon Garon has argued that these helped to raise the household saving rate in Japan. $^{8}$

Ninth, many attribute Japan's high household saving rate to cultural factors. They argue that frugality, considered a virtue in Confucian teachings, is part of the national character of the Japanese people.

However, all of these factors are becoming less and less applicable over time. (1) Double-digit rates of economic growth ended in the early 1970s, and income growth rates have been embarrassingly low in recent years, especially in the 1990s; (2) Japanese households have accumulated high levels of assets (see below); (3) consumer credit has become widely available (see below), (4) most companies have scaled back bonuses as a result of the prolonged recession, (5) Japan's population is aging at an unprecedented rate, with the share of the population aged 65 or older to the total population rising from 7.9 percent (next to last place) in 1975 to 17.2 percent (third place) in 2000 (see Table 2); (6) most tax breaks for saving were abolished in 1988; (7) public old-age pension benefits were dramatically improved in 1973; (8) government saving promotion activities have been scaled back, and the Central Council for Savings Promotion was renamed the Central Council for Savings Information in 1988, due in large part 
to pressure from Japan's trading partners, although private sector initiatives remain; and (9) the longstanding culture of thrift may decline over time as foreign influences infiltrate the country. The weakening of these factors can explain why Japan's household saving rate has declined so sharply since the mid-1970s.

(4) Will the Japanese Once Again Become Big Savers? In my opinion, the most important factor determining future trends in Japan's household saving rate will be the rapid aging of the population. Japan's population is aging rapidly and will soon become the most aged in the world. As Table 2 shows, the share of the population aged 65 or older to the total population in Japan is projected to increase from 17.2 percent in 2000 to 28.9 percent (highest among the OECD member countries) in 2025. An aged population will save at lower rates, just as a younger population will save at higher levels, according to the life cycle hypothesis. When young, individuals generally work and save a portion of their incomes, while after retirement, they dissave their previously accumulated savings. Thus, the rapid aging of Japan's population has presumably contributed to the sustained decline in its household saving rate in recent years. With the aging of Japan's population projected to continue at a rapid rate, the decline in its household saving rate can also be expected to continue at a rapid rate. Indeed, a number of authors, myself included, have calculated that the rapid aging of Japan's population will cause Japan's household saving rate to decline to zero or even negative levels by around $2010 .^{9}$

I should note, however, that the discussion thus far has focused exclusively on the impact of the aging of the population on the household saving rate. There are, of course, other factors that will influence the household saving rate, and I now discuss four short-term factors that may have been important during the current recession that began in $1991 .^{10}$

First, sharp declines in land and equity prices have led to sharp declines in the value of 
household holdings of land and equities, and this in turn should have encouraged households to save more in order to make up for the capital losses on their land and equity holdings.

Second, the current recession has undoubtedly increased the anxieties that the Japanese harbor about future income and employment prospects, living expenses during old age, and public old-age pensions. These increased anxieties should also have encouraged households to save more.

Third, consumer price deflation has continued for a number of years. It, too, should have encouraged households to save more because, in a situation in which consumer prices are declining over time, households can save money by postponing their purchases of consumer goods and services. However, consumer price deflation will also increase the real value of household holdings of financial assets, which in turn will induce people to consume more and save less. In short, the net impact of consumer price deflation on the household saving rate is theoretically ambiguous.

Fourth, the profits of individual proprietors have been stagnant during the current recession, and this has lessened their ability to save, thereby lowering the saving rate of the household sector as a whole.

In sum, two of these short-term factors should have held up Japan's household saving rate during the past decade, one of them should have put downward pressure thereon, and one of them appears to be ambiguous in its impact. Thus, even if the Japanese economy recovers from the current recession and these short-term factors cease to apply, recovery should not have a substantial impact on Japan's household saving rate. In either event, I predict that Japan's household rate will continue its rapid decline.

\section{Are the Japanese Asset-Rich?}


High saving rates usually lead to high asset or wealth holdings because wealth is simply the cumulation of past saving. Thus, in this subsection, I turn my attention from saving to wealth and consider whether the asset or wealth holdings of the Japanese are high absolutely as well as relative to the other industrialized countries.

Table 3 shows data on household wealth and indebtedness for the Group of Seven (G7) countries for the 1990-2001 period. Looking first at data on net wealth or net worth (the broadest concept of wealth, defined as financial assets plus non-financial or real assets minus liabilities), Japan ranked first among the G7 countries in all four of the years for which data are shown even though net wealth or net worth declined sharply after 1990 due to the collapse of the bubble (the collapse of land and equity prices)--from a whopping 9.5 times household disposable income in 1990 to 7.5 to 7.6 times household disposable income in 1995, 2000, and 2001. The corresponding ratio was 6.4 to 7.5 times in Italy, 5.6 to 7.5 times in the United Kingdom, 5.1 to 6.3 times in France, 5.4 to 5.8 times in Germany, 4.7 to 5.9 times in the United States, and 4.2 to 5.1 times in Canada.

Moreover, the individual components of household wealth were also generally much higher in Japan. For example, Japan ranked first among the G7 countries with respect to financial assets in three out of the four years for which data are shown $(1990,1995$, and 2001) and was second behind the United Kingdom in the remaining year (2000), with financial asset holdings ranging from 4.0 to 4.8 times household disposable income. Similarly, Japan ranked second behind Italy among the G7 countries with respect to non-financial or real assets (land, housing, and consumer durables) in three out of the four years for which data are shown (1995, 2000, and 2001) and was first in the remaining year (1990), with holdings of non-financial or real assets ranging from 4.1 to 6.8 times household disposable income. Finally, Japan ranked first among the G7 countries with respect to total assets (the sum of financial assets and 
non-financial assets) in all four years for which data are shown, with total asset holdings ranging from 8.9 to 10.8 times household disposable income.

In terms of trends over time, non-financial or real assets declined sharply throughout the 1990-2001 period due to the sharp decline in land prices while financial assets continued to increase throughout this period despite the sharp decline in equity prices. As a result of these conflicting trends, both total assets and net wealth or net worth declined sharply between 1990 and 1995 but stabilized thereafter.

Thus, it appears that the Japanese are indeed asset-rich both absolutely as well as relative to the other G7 countries. This enormous wealth of the Japanese is presumably due partly to their high saving rates and partly to the rapid increase in land and equity prices during much of the postwar period, but since Japanese household saving rates are no longer unusually high and since land and equity prices have been plummeting for more than a decade, both the level of household wealth in Japan and the gap in household wealth between Japan and the other G7 countries are much lower now than they were a decade ago and can be expected to decline even further in the future.

\section{Do the Japanese Shun Borrowing?}

Typically, high saving and low borrowing go hand in hand because both are manifestations of frugality and both are ways of holding down consumption. Thus, in this section, I turn my attention to the borrowing side of the ledger. As Table 3 shows, Japan ranked first among the G7 countries with respect to outstanding liabilities in all four of the years for which data are shown, with outstanding liabilities ranging from 1.3 to 1.4 times household disposable income in Japan, as compared to 1.1 to 1.2 times in the United Kingdom, 0.9 to 1.2 times in Canada, 0.9 to 1.1 times in the United States, 0.7 to 1.1 times in Germany, 0.7 to 0.8 
times in France, and 0.3 to 0.4 times in Italy. Moreover, even though conventional wisdom is that household liabilities consist mostly of mortgages (housing loans) in Japan, the share of mortgages in household liabilities is much lower in Japan than it is in all of the other G7 countries in all four of the years for which data are shown, ranging from 39 to 45 percent in Japan, as compared to 70 to 73 percent in the United Kingdom, 68 to 76 percent in France, 67 to 70 percent in the United States, 61 to 77 percent in Germany, 61 to 67 percent in Canada, and 47 to 74 percent in Italy (see Table 4). Thus, in Japan, household debt is used to finance consumption to a greater extent than it is in the other G7 countries.

Data for the more distant past show that outstanding liabilities were merely 60 and 77 percent of household disposable income in Japan in 1970 and 1980, respectively, indicating that the Japanese did, in fact, shun borrowing in the past. (The data presented in the Andrew Gordon paper in this volume corroborate my finding that consumer credit did not "take off" in Japan until the late 1980s.) However, Japanese households now borrow more than consumers in the other industrialized countries and their household debt is used to finance consumption to a greater extent than in the other industrialized countries. This dramatic change is presumably due partly to changes in consumer attitudes and partly to the rapid development of credit markets in recent years.

\section{Are Japanese Household Portfolios Unusually Conservative?}

As Table 4 shows, Japan ranks lowest among the G7 countries with respect to the share of equities in financial assets in three of the four years for which data are shown (1995, 2000, and 2001). In 1990, it ranked second from the bottom (ahead of Germany), but this was during the bubble period when equity prices were temporarily inflated. The share of equities in financial assets has ranged from 7-14 percent in Japan, as compared to 34-46 percent 
in France, 18-45 percent in Italy, 15-31 percent in the United States, 18-28 percent in Canada, 18-23 percent in the United Kingdom, and 6-27 percent in Germany.

These data confirm that Japanese households are the most conservative in the G7, investing only a small share of their assets in equities and a correspondingly large share in bank and postal deposits and land/housing. This conservative portfolio can presumably be explained in large part by such factors as: (1) the high brokerage fees charged by securities companies, (2) the large minimum lot sizes when buying and selling equities, (3) consumer mistrust of securities companies arising from widely publicized scandals involving securities companies, (4) tax breaks for saving (which applied mostly to bank and postal deposits), (5) the lack of consumer financial education, (6) the high price of land and housing, and (7) a higher degree of risk aversion in Japan. The collapse of equity prices in the early 1990s and their continued stagnation since then also partially explain the low share of equities in Japan. Indeed, the decline in the share of equities in financial assets from 14.4 percent in 1990 to 7.1 percent in 2001 is attributable to the collapse and continued stagnation of equity prices. However, the collapse of the Tokyo stock market cannot be the only explanation of the low share of equities in Japan because it was already the second lowest among the G7 countries in 1990, even before the collapse of equity prices.

To summarize, the Japanese used to be big savers, but they no longer are. They used to rely relatively little on borrowing, but they do now. The Japanese do, however, continue to hold a high level of assets and to hold conservative portfolios.

\section{The Consumption Behavior of the Japanese}

To what extent has consumption behavior in Japan changed over time, and how does it 
compare to that in the other industrialized countries? Let us examine data on both consumption levels and the composition of consumption. ${ }^{11}$

\section{Are the Japanese Big Spenders?}

How do Japanese consumption levels compare to those in the other G7 countries? Since the figures for each country are expressed in the currency of that country, it is necessary to convert the figures for each country into a common currency (say, U.S. dollars) when making inter-country comparisons. If this is done using market exchange rates, the figures will be biased to the extent that price levels vary from country to country. Indeed, because of Japan's high price levels, market exchange rates would lead us to conclude erroneously that the Japanese consume at levels far above the average of both the G7 and OECD countries. ${ }^{12}$ It is therefore preferable to convert the figures for each country to a common currency using purchasing power parities, which take account of differences in price levels among countries.

Table 5 presents data on per capita household final consumption expenditure in Japan and the other G7 countries during the 1970-2001 period in U.S. dollars, with the conversion to U.S. dollars being done using purchasing power parities. Japanese consumption levels showed considerable improvement during much of this period but continued to lag far behind the free-spending Americans and also lagged behind the other G7 and OECD member countries. Consumption levels in Japan improved sharply from 44.4 percent of U.S. levels in 1970 to 58.4 percent in 1985. As measured against the G7 average, Japanese consumption levels rose from 70.7 percent in 1970 to 87.4 percent in 1985 . And relative to the OECD average, Japanese consumption levels increased from 72.6 percent in 1970 to 92.8 percent in 1985 . However, it is noteworthy that Japanese consumption levels have not improved relatively since then, remaining at 58-60 percent of U.S. levels, 87-88 percent of the G7 average, and 93-94 percent 
of the OECD average. With respect to Japan's rank among the G7 countries, Japan ranked seventh (last) in 1970, sixth (ahead of the United Kingdom) in 1985, and sixth (ahead of France) in 2000 and 2001.

By contrast, the United States stands out as a colossus of consumption throughout this period (see Lizabeth Cohen's essay in this volume). Despite expanding consumption in the other G7 countries, no other G7 country managed to consume at more than 69 percent of U.S levels during the 1970-2001 period. To be sure, Japanese consumption levels have been at or near the bottom of the G7 countries, but notwithstanding Japan's reputation for uniqueness, it is the United States that jumps off the charts when it comes to consumption.

\section{Are Japanese Consumption Patterns Unique?}

Having established that Japan, like the other G7 countries, consumes at levels far below that of the United States, I now compare the composition of consumption in Japan to that in the other G7 countries.

The most important indicator of consumption patterns is the so-called Engel coefficient (defined as the budget share of food and non-alcoholic beverages), and needless to say, a lower Engel coefficient is indicative of a higher standard of living. As the (constant-price) data I analyze elsewhere show, ${ }^{13}$ Japan's Engel coefficient was very high (55.9 percent) just after the Second World War, but it has shown a phenomenal decline (improvement) during the postwar period, falling to 45.4 percent in $1955,35.4$ percent in $1965,27.6$ percent in 1975, and 22.2 percent in 1985.

Table 6 shows a twelve-way breakdown of the final consumption expenditure of households by purpose for the G7 countries for 1990 and 2001, and as this table shows, Japan's Engel coefficient declined further to 16.5 percent in 1990 and 14.2 percent in 2001 . Thus, 
Japan's Engel coefficient is now only about one-quarter of what it was a half century ago.

Despite this phenomenal improvement, however, Japan's Engel coefficient was still the second highest among the G7 countries in both 1990 and 2001. In 1990, it was 16.5 percent, behind first-place Italy (18.2 percent) but well above the G7 average of 13.4 percent and the last-place country (the United States) (8.5 percent), and in 2001, it was 14.2 percent, behind first-place Italy (15.1 percent) but well above the G7 average of 11.8 percent and the last-place country (the United States) $(7.1$ percent). Moreover, although Japan's Engel coefficient declined somewhat between 1990 and 2001 in absolute terms, it has shown little or no relative improvement during this time period: the ratio of Japan's Engel coefficient to the G7 average declined slightly from 1.23 to 1.21 times, but its ratio to the U.S. figure increased slightly from 1.94 to 2.01 times, and it is now slightly more than twice the U.S. figure.

Turning to a discussion of the other categories of consumption, the most unusual features of consumption patterns in Japan (aside from the high Engel coefficient) are the relatively low shares of "transport," "furnishings, household equipment and routine maintenance of the house," and "health" in both 1990 and 2001, the relatively low share of "restaurants and hotels" in 1990, the relatively low share of "clothing and footwear" in 2001, the relatively high share of "recreation and culture" in both 1990 and 2001, and the relatively high share of "housing, water, electricity, gas and other fuels" in 2001 (see Table 6).

Japan's consumption patterns look more "backward" than those of the other G7 countries at first glance inasmuch as the budget shares of necessities such as food and housing are relatively high and the budget shares of luxuries such as transport, furnishings/household equipment/etc., health, and restaurants/hotels are relatively low (the main exceptions being that the budget share of clothing (a necessity) is relatively low and that the budget share of recreation/culture (a luxury) is relatively high). However, Japan's consumption patterns are 
heavily influenced by factors other than income levels. For example, Japan's high Engel coefficient is due in large part to the much higher food prices in Japan, which in turn are due to the scarcity of arable land, government regulation of food prices, and restrictions on food imports. Similarly, the high budget share of housing in Japan is due in large part to high rents, which, in turn, are due in large part to the scarcity of land; the low budget share of transport is due in large part to the low automobile ownership rate, which, in turn, is due in large part to high gasoline prices, high expressway tolls, high parking fees, and the availability of public transportation; and the low budget share of health in Japan is due in large part to a presence of a universal national health insurance program.

To summarize, Japan showed phenomenal improvement in consumption levels and consumption patterns during the postwar period, and as a result, its consumption levels and consumption patterns are now roughly comparable to those of the other G7 countries but are still well behind those of the United States.

\section{Conclusions}

This chapter has analyzed the saving and consumption behavior of the Japanese, examining trends over time as well as comparisons with the other industrialized countries (mostly the Group of Seven countries). Are the conventional wisdoms about Japanese saving and consumption behavior correct? Yes and no, depending on which behavior and which period one is discussing. The Japanese were big savers during parts of the prewar, wartime, and early postwar periods and throughout the 1955-95 period but not any longer, and household saving rates can be expected to decline even further in the future. The Japanese did used to shun borrowing but not any longer. The Japanese are still wealthy despite the decline 
in equity and land prices, and the Japanese $d o$ continue to hold conservative portfolios. Finally, although the Japanese steadily increased their consumption levels during the postwar period, they still do not consume quite as much as most other G7 countries and far less than Americans, and although the consumption patterns of the Japanese improved dramatically during the postwar period, Japan's consumption patterns are still not quite as affluent as those of most other G7 countries and far less affluent than those of the United States.

Are the Japanese unique? No, the saving and consumption behavior of the Japanese is admittedly quite different from that of the Anglo-Saxon countries (Canada, the United Kingdom, and the United States), which have low household saving rates, low net wealth, low real assets, high consumption levels, and low Engel coefficients. However, Japanese saving and consumption behavior is surprisingly similar to that of the continental European countries--France, Germany, and especially Italy, all of which exhibit a high household saving rate, high net worth, high real assets, low consumption levels, and high Engel coefficients. On the other hand, Japan (and Germany) more closely resemble the Anglo-Saxon countries with respect to high levels of both financial assets and liabilities. With respect to total assets and equity shares, there appear to be no systematic differences between Continental Europe/Japan and the Anglo-Saxon countries. Interestingly, Italy fits the conventional wisdoms about Japan more closely than Japan itself. Italy not only has a high household saving rate, high net worth, and high real assets but its household saving rate has historically surpassed even Japan's, its real assets today exceed those of Japan, and it has low liabilities, unlike Japan.

An analysis of the striking differences in saving and consumption behavior between Continental Europe/Japan and the Anglo-Saxon countries awaits another paper. However, one explanation may be that high land/housing prices--combined with capital market imperfections and a strong desire for homeownership--in Continental Europe/Japan led to the high household 
saving rates, high net wealth, high real assets, low financial assets, and low liabilities in these countries. ${ }^{14}$ In any event, all too often, scholars compare Japan only to the United States, but such narrow comparisons create the false impression that Japan is unique. We should bear in mind that Japan and Continental Europe are quite similar in many ways and avoid exaggerating the distinctiveness of Japan. When it comes to saving and consumption, it is American exceptionalism (together with that of Canada and the United Kingdom) that demands further study. 
Figure 1: Trends in Japan's Household Saving Rate, 1955-2002

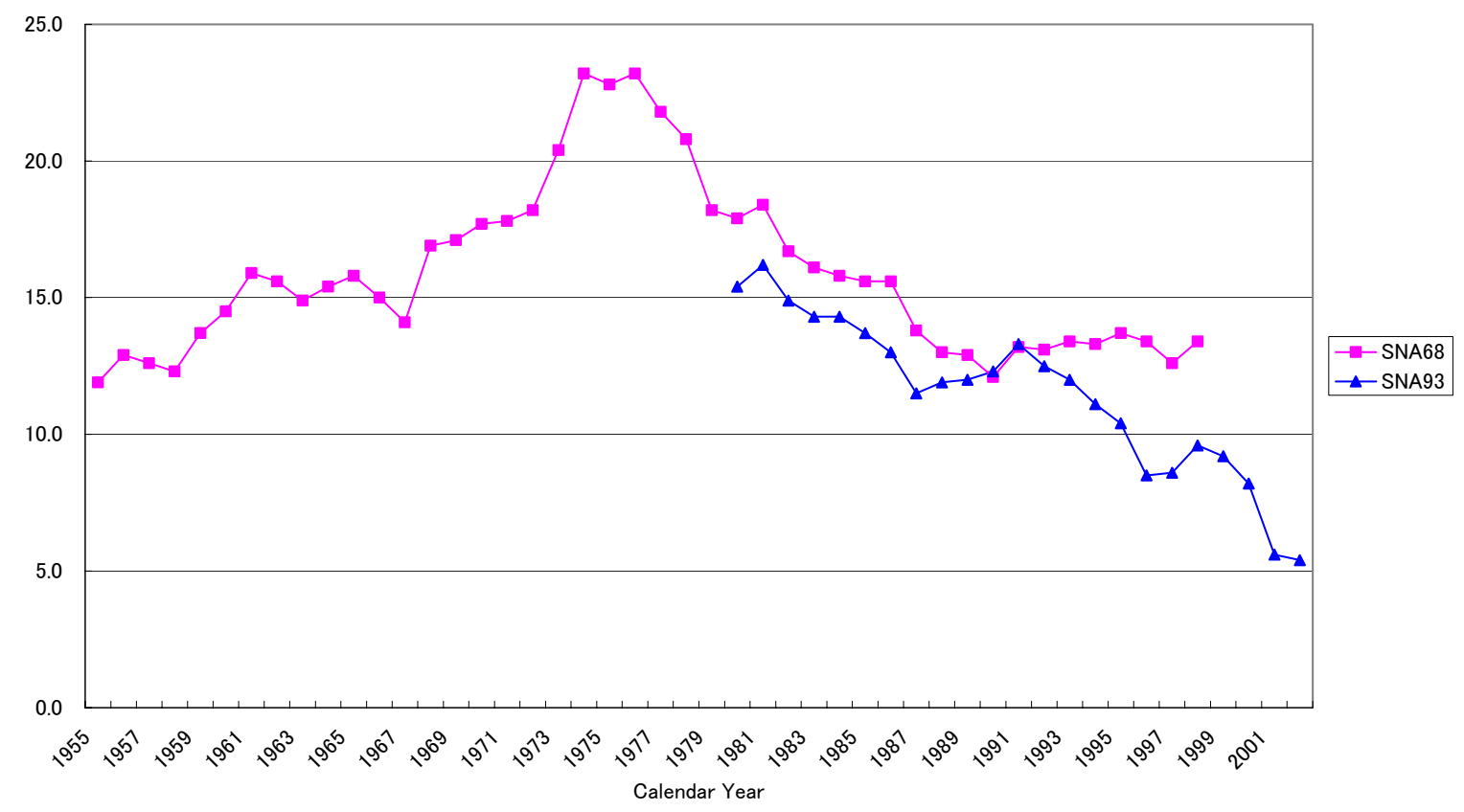

Notes: The line marked "SNA68" shows data based on the United Nations' System of National Accounts 1968, whereas the line marked "SNA93" shows data based on the United Nations' System of National Accounts 1993. Payments in kind for medical and other services from social insurance have been added to the denominator of the SNA93 figures to make them comparable to the SNA68 figures.

Source: Department of National Accounts, Economic and Social Research Institute, Cabinet Office, Government of Japan, ed., Annual Report on National Accounts, 2004 edition (Tokyo: National Printing Bureau, 2004), and earlier editions of the same. 
Data for Figure 1: Trends in Japan's Household Saving Rate, 1955-2002

\begin{tabular}{|c|c|c|}
\hline Calendar Year & SNA68 & SNA93 \\
\hline 1955 & 11.9 & \\
\hline 1956 & 12.9 & \\
\hline 1957 & 12.6 & \\
\hline 1958 & 12.3 & \\
\hline 1959 & 13.7 & \\
\hline 1960 & 14.5 & \\
\hline 1961 & 15.9 & \\
\hline 1962 & 15.6 & \\
\hline 1963 & 14.9 & \\
\hline 1964 & 15.4 & \\
\hline 1965 & 15.8 & \\
\hline 1966 & 15.0 & \\
\hline 1967 & 14.1 & \\
\hline 1968 & 16.9 & \\
\hline 1969 & 17.1 & \\
\hline 1970 & 17.7 & \\
\hline 1971 & 17.8 & \\
\hline 1972 & 18.2 & \\
\hline 1973 & 20.4 & \\
\hline 1974 & 23.2 & \\
\hline 1975 & 22.8 & \\
\hline 1976 & 23.2 & \\
\hline 1977 & 21.8 & \\
\hline 1978 & 20.8 & \\
\hline 1979 & 18.2 & \\
\hline 1980 & 17.9 & 15.4 \\
\hline 1981 & 18.4 & 16.2 \\
\hline 1982 & 16.7 & 14.9 \\
\hline 1983 & 16.1 & 14.3 \\
\hline 1984 & 15.8 & 14.3 \\
\hline 1985 & 15.6 & 13.7 \\
\hline 1986 & 15.6 & 13.0 \\
\hline 1987 & 13.8 & 11.5 \\
\hline 1988 & 13.0 & 11.9 \\
\hline 1989 & 12.9 & 12.0 \\
\hline 1990 & 12.1 & 12.3 \\
\hline 1991 & 13.2 & 13.3 \\
\hline 1992 & 13.1 & 12.5 \\
\hline 1993 & 13.4 & 12.0 \\
\hline 1994 & 13.3 & 11.1 \\
\hline 1995 & 13.7 & 10.4 \\
\hline 1996 & 13.4 & 8.5 \\
\hline 1997 & 12.6 & 8.6 \\
\hline 1998 & 13.4 & 9.6 \\
\hline 1999 & & 9.2 \\
\hline 2000 & & 8.2 \\
\hline 2001 & & 5.6 \\
\hline 2002 & & 5.4 \\
\hline
\end{tabular}


Table 1: Net Household Saving Rates of Selected OECD Countries, 1985-2002

\begin{tabular}{lcrrrrrrrrr}
\hline & 1985 & & 1990 & & 1995 & & 2000 & \multicolumn{2}{c}{2002} & \\
\hline Australia & 10.8 & 7 & 9.3 & 9 & 4.8 & $17 \mathrm{~T}$ & 3.4 & $16 \mathrm{~T}$ & 0.6 & 19 \\
Austria & 10.5 & 8 & 14.0 & $4 \mathrm{~T}$ & 11.7 & 7 & 8.3 & 8 & 7.6 & $8 \mathrm{~T}$ \\
*Belgium & 11.1 & 6 & 12.1 & 8 & 13.2 & 5 & 9.2 & 7 & 10.1 & 5 \\
Canada & 15.8 & 3 & 13.0 & 7 & 9.2 & 12 & 4.6 & 15 & 4.2 & 16 \\
Czech Rep. & na & & na & & 20.6 & 1 & 13.0 & 1 & 11.3 & 2 \\
*Denmark & na & & 7.8 & $11 \mathrm{~T}$ & 4.8 & $17 \mathrm{~T}$ & 3.4 & $16 \mathrm{~T}$ & 5.0 & 15 \\
Finland & 3.4 & 14 & 1.8 & 16 & 4.8 & $17 \mathrm{~T}$ & -1.4 & 20 & -1.4 & 20 \\
France & 8.9 & 10 & 7.8 & $11 \mathrm{~T}$ & 11.2 & $9 \mathrm{~T}$ & 11.0 & 3 & 12.0 & 1 \\
Germany & 12.1 & 5 & 13.7 & 6 & 11.2 & $9 \mathrm{~T}$ & 9.8 & $5 \mathrm{~T}$ & 10.6 & 4 \\
*Italy & 21.5 & 1 & 19.5 & 2 & 15.8 & 3 & 10.1 & 4 & 11.1 & 3 \\
Japan & 16.5 & 2 & 14.0 & $4 \mathrm{~T}$ & 11.9 & 6 & 9.8 & $5 \mathrm{~T}$ & 5.9 & 13 \\
South Korea & 14.8 & 4 & 22.0 & 1 & 16.8 & 2 & 11.5 & 2 & 7.6 & $8 \mathrm{~T}$ \\
Netherlands & 5.6 & 13 & 17.5 & 3 & 14.4 & 4 & 6.8 & 11 & 8.6 & 6 \\
New Zealand & 1.3 & 16 & 0.7 & 18 & -3.8 & 21 & -4.1 & 21 & -5.2 & 21 \\
Norway & -3.3 & 17 & 1.5 & 17 & 4.6 & 20 & 4.5 & 13 & 6.9 & 11 \\
*Portugal & na & & na & & 9.5 & 11 & 7.6 & $9 \mathrm{~T}$ & 8.5 & 7 \\
*Spain & 7.8 & 11 & 8.6 & 10 & 11.3 & 8 & 7.6 & $9 \mathrm{~T}$ & 7.4 & 10 \\
*Sweden & 2.2 & 15 & 0.0 & 19 & 5.8 & 15 & 1.7 & 19 & 5.7 & 14 \\
*Switzerland & na & & 6.1 & 14 & 6.6 & 14 & 5.8 & 12 & 6.8 & 12 \\
*United Kingdom & 6.9 & 12 & 5.6 & 15 & 7.0 & 13 & 3.9 & 14 & 3.7 & $17 \mathrm{~T}$ \\
United States & 9.2 & 9 & 7.8 & $11 \mathrm{~T}$ & 5.6 & 16 & 2.8 & 18 & 3.7 & $17 \mathrm{~T}$ \\
\hline OECD Mean & 9.1 & & 9.6 & & 9.4 & & 6.2 & & 6.2 & \\
\hline
\end{tabular}

Notes: The left-hand figures denote the household saving rate, defined as household saving as a ratio of disposable household income, while the right-hand figures denote the rank of each country. "na" denotes "not available," while "T" denotes "tie." The first figure for New Zealand is the figure for 1986 because the figure for 1985 was not available. The figures include the saving of households as well as that of non-profit institutions except in the case of the Czech Republic, Finland, France, Japan, and New Zealand. For countries marked by an asterisk, only figures on gross household saving rates were available, and the gross figures were converted to a net basis by using a conversion factor of 0.7 (which is the approximate ratio of the average net household saving rate to the average gross household saving rate for the countries and years used in the present analysis).

Source: OECD Economic Outlook, vol. 2003/1, no. 73 (June 2003); vol. 2003/2, no. 74 (December 2003), Annex Table 24. 
Table 1A: Household Saving Rates of Selected OECD Countries, 1985-2002

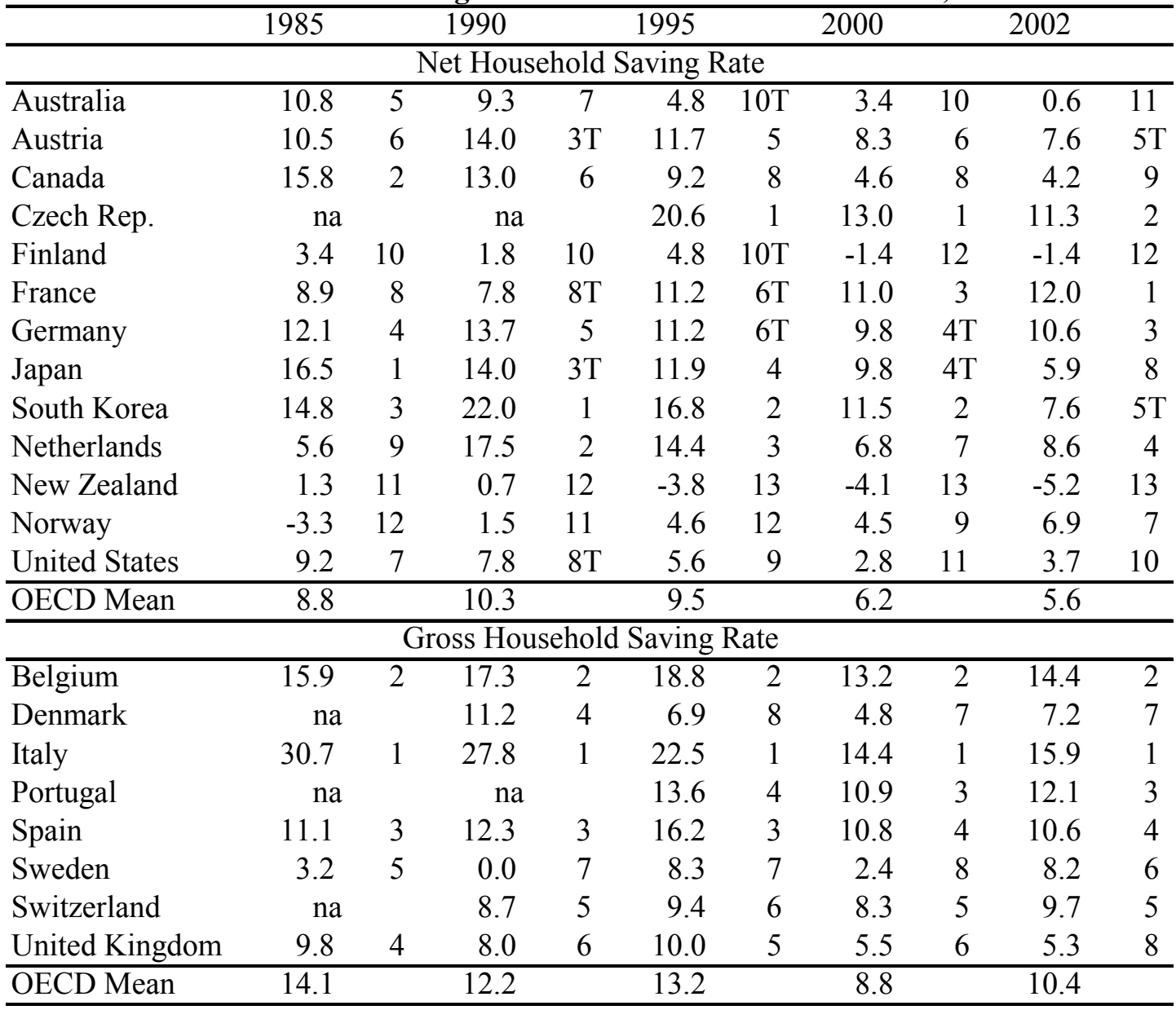

Notes: See Table 1.

Source: The same as Table 1. 
Table 2: Share of the Aged Population in Selected OECD Countries, 1975-2025

\begin{tabular}{lrrrrrr}
\hline Country & 1975 & & 2000 & & 2025 & \\
\hline Australia & 8.7 & $17 \mathrm{~T}$ & 12.3 & $18 \mathrm{~T}$ & 18.6 & 18 \\
Austria & 14.9 & 2 & 15.6 & $10 \mathrm{~T}$ & 24.3 & 7 \\
Belgium & 13.9 & 5 & 17.0 & $4 \mathrm{~T}$ & 23.7 & 8 \\
Canada & 8.5 & 19 & 12.6 & 17 & 20.7 & $16 \mathrm{~T}$ \\
Czech Rep. & 12.9 & 9 & 13.8 & 15 & 23.1 & 10 \\
Denmark & 13.4 & 8 & 15.0 & 13 & 22.5 & 11 \\
Finland & 10.6 & 13 & 14.9 & 14 & 25.2 & 5 \\
France & 13.5 & 7 & 16.0 & $7 \mathrm{~T}$ & 22.2 & 12 \\
Germany & 14.8 & 3 & 16.4 & 6 & 24.6 & 6 \\
Italy & 12.0 & 11 & 18.1 & 1 & 25.7 & 3 \\
Japan & 7.9 & 20 & 17.2 & 3 & 28.9 & 1 \\
South Korea & 3.6 & 21 & 7.1 & 21 & 16.9 & 21 \\
Netherlands & 10.8 & 12 & 13.6 & 16 & 21.9 & $13 \mathrm{~T}$ \\
New Zealand & 8.7 & $17 \mathrm{~T}$ & 11.7 & 20 & 18.5 & $19 \mathrm{~T}$ \\
Norway & 13.7 & 6 & 15.4 & 12 & 21.8 & 15 \\
Portugal & 9.9 & 16 & 15.6 & $10 \mathrm{~T}$ & 20.7 & $16 \mathrm{~T}$ \\
Spain & 10.0 & 15 & 17.0 & $4 \mathrm{~T}$ & 23.6 & 9 \\
Sweden & 15.1 & 1 & 17.4 & 2 & 25.4 & 4 \\
Switzerland & 12.6 & 10 & 16.0 & $7 \mathrm{~T}$ & 27.1 & 2 \\
United Kingdom & 14.0 & 4 & 15.8 & 9 & 21.9 & $13 \mathrm{~T}$ \\
United States & 10.5 & 14 & 12.3 & $18 \mathrm{~T}$ & 18.5 & $19 \mathrm{~T}$ \\
\hline OECD Mean & 11.4 & & 14.8 & & 22.7 & \\
\hline & & & & & &
\end{tabular}

Notes: The left-hand figures denote the share of the population aged 65 or older to the total population, while the right-hand figures denote the rank of each country. "na" denotes "not available," while "T" denotes "tie."

Source: United Nations, World Population Ageing, 1950-2050 (New York, N.Y.: United Nations, 2002). 
Table 3: Household Wealth and Indebtedness in the Group of Seven Countries, 1990-2001

\begin{tabular}{|c|c|c|c|c|c|c|c|c|}
\hline \multirow{2}{*}{ Canada } & \multicolumn{2}{|l|}{1990} & \multicolumn{2}{|l|}{1995} & \multicolumn{2}{|l|}{2000} & \multicolumn{2}{|l|}{2001} \\
\hline & & & & & & & & \\
\hline Net wealth & 416.5 & 7 & 483.7 & 7 & 506.7 & 7 & 507.4 & 7 \\
\hline Net financial wealth & 177.5 & 5 & 225.7 & 4 & 244.1 & 6 & 238.1 & 6 \\
\hline Non-financial assets & 239.0 & 6 & 258.0 & 6 & 262.6 & 6 & 269.3 & 6 \\
\hline Financial assets & 270.4 & 4 & 329.1 & 4 & 357.1 & 5 & 353.2 & 4 \\
\hline of which: Equities & 49.6 & 5 & 66.3 & 4 & 94.4 & 5 & 98.6 & 4 \\
\hline Total assets & 509.4 & 7 & 587.1 & 6 & 619.7 & 7 & 622.5 & 6 \\
\hline Liabilities & 92.9 & 3 & 103.4 & 3 & 113.0 & 4 & 115.2 & 3 \\
\hline of which: Mortgages & 59.2 & 3 & 68.8 & 2 & 69.8 & 4 & 69.9 & 4 \\
\hline \multicolumn{9}{|l|}{ France } \\
\hline Net wealth & 541.8 & 4 & 507.6 & 6 & 629.3 & 4 & 613.6 & 4 \\
\hline Net financial wealth & 169.6 & 6 & 195.0 & 6 & 282.6 & 5 & 255.1 & 4 \\
\hline Non-financial assets & 372.2 & 5 & 312.6 & 4 & 346.7 & 5 & 358.6 & 4 \\
\hline Financial assets & 248.3 & 5 & 262.9 & 5 & 359.2 & 4 & 336.7 & 5 \\
\hline of which: Equities & 114.1 & 1 & 89.6 & 2 & 155.7 & 1 & 129.8 & 1 \\
\hline Total assets & 620.5 & 4 & 575.5 & 7 & 705.9 & 4 & 695.3 & 4 \\
\hline Liabilities & 78.7 & 5 & 67.9 & 6 & 76.6 & 6 & 81.7 & 6 \\
\hline of which: Long-term loans & 53.4 & 5 & 51.6 & 6 & 55.2 & 6 & 55.6 & 6 \\
\hline \multicolumn{9}{|l|}{ Germany } \\
\hline Net wealth & 535.6 & 5 & 563.1 & 3 & 583.9 & 6 & 568.5 & 5 \\
\hline Net financial wealth & 130.8 & 7 & 135.6 & 7 & 162.9 & 7 & 159.0 & 7 \\
\hline Non-financial assets & 404.8 & 3 & 360.6 & 3 & 351.0 & 4 & 340.4 & 5 \\
\hline Financial assets & 200.7 & 7 & 236.2 & 7 & 277.3 & 7 & 270.9 & 7 \\
\hline of which: Equities & 11.6 & 7 & 42.3 & 7 & 74.8 & 6 & 67.8 & 6 \\
\hline Total assets & 605.5 & 5 & 596.8 & 5 & 628.3 & 6 & 611.3 & 7 \\
\hline Liabilities & 70.0 & 6 & 100.6 & 4 & 114.4 & 3 & 112.0 & 4 \\
\hline of which: Mortgages & 53.6 & 4 & 61.0 & 4 & 72.5 & 2 & 72.1 & 3 \\
\hline \multicolumn{9}{|l|}{ Italy } \\
\hline Net wealth & 636.9 & 2 & 699.3 & 2 & 748.3 & 3 & 714.2 & 2 \\
\hline Net financial wealth & 196.3 & 4 & 224.0 & 5 & 294.6 & 4 & 251.7 & 5 \\
\hline Non-financial assets & 440.5 & 2 & 475.3 & 1 & 453.7 & 1 & 462.5 & 1 \\
\hline Financial assets & 225.4 & 6 & 254.6 & 6 & 329.8 & 6 & 287.0 & 6 \\
\hline of which: Equities & 46.0 & 6 & 46.5 & 5 & 147.4 & 3 & 102.5 & 3 \\
\hline Total assets & 665.9 & 3 & 729.9 & 2 & 783.5 & 3 & 749.5 & 3 \\
\hline Liabilities & 29.1 & 7 & 30.6 & 7 & 35.3 & 7 & 35.3 & 7 \\
\hline $\begin{array}{l}\text { of which: Medium and } \\
\text { long-term loans }\end{array}$ & 13.7 & 7 & 18.6 & 7 & 25.7 & 7 & 26.0 & 7 \\
\hline \multicolumn{9}{|l|}{ Japan } \\
\hline Net wealth & 947.6 & 1 & 757.1 & 1 & 762.3 & 1 & 753.1 & 1 \\
\hline Net financial wealth & 268.0 & 1 & 289.1 & 2 & 344.0 & 3 & 344.7 & 1 \\
\hline Non-financial assets & 679.6 & 1 & 468.0 & 2 & 419.3 & 2 & 408.4 & 2 \\
\hline Financial assets & 398.8 & 1 & 426.2 & 1 & 477.7 & 2 & 483.5 & 1 \\
\hline of which: Equities & 57.3 & 3 & 45.9 & 6 & 42.8 & 7 & 34.4 & 7 \\
\hline Total assets & 1078.4 & 1 & 894.2 & 1 & 897.0 & 1 & 891.9 & 1 \\
\hline Liabilities & 130.8 & 1 & 137.1 & 1 & 133.7 & 1 & 138.8 & 1 \\
\hline of which: Mortgages & 50.6 & 6 & 58.5 & 5 & 59.3 & 5 & 61.9 & 5 \\
\hline
\end{tabular}


Table 3 (continued)

\begin{tabular}{|c|c|c|c|c|c|c|c|c|}
\hline \multicolumn{9}{|l|}{ United Kingdom } \\
\hline Net wealth & 611.0 & 3 & 555.9 & 4 & 748.8 & 2 & 682.3 & 3 \\
\hline Net financial wealth & 214.1 & 3 & 281.3 & 3 & 377.5 & 1 & 314.4 & 3 \\
\hline Non-financial assets & 396.9 & 4 & 270.2 & 5 & 370.9 & 3 & 370.2 & 3 \\
\hline Financial assets & 329.9 & 3 & 387.8 & 3 & 493.1 & 1 & 433.1 & 3 \\
\hline of which: Equities & 61.2 & 2 & 71.7 & 3 & 110.9 & 4 & 78.8 & 5 \\
\hline Total assets & 726.8 & 2 & 658.0 & 3 & 863.9 & 2 & 803.4 & 2 \\
\hline Liabilities & 115.8 & 2 & 106.5 & 2 & 115.6 & 2 & 118.7 & 2 \\
\hline of which: Mortgages & 81.3 & 1 & 78.1 & 1 & 83.5 & 1 & 85.7 & 1 \\
\hline \multicolumn{9}{|l|}{ United States } \\
\hline Net wealth & 474.5 & 6 & 508.2 & 5 & 587.4 & 5 & 555.6 & 6 \\
\hline Net financial wealth & 259.0 & 2 & 304.5 & 1 & 370.3 & 2 & 330.3 & 2 \\
\hline Non-financial assets & 215.5 & 7 & 203.7 & 7 & 217.1 & 7 & 225.4 & 7 \\
\hline Financial assets & 345.6 & 2 & 398.3 & 2 & 475.2 & 3 & 439.1 & 2 \\
\hline of which: Equities & 52.1 & 4 & 97.7 & 1 & 147.6 & 2 & 122.5 & 2 \\
\hline Total assets & 561.1 & 6 & 601.9 & 4 & 692.3 & 5 & 664.5 & 5 \\
\hline Liabilities & 86.6 & 4 & 93.7 & 5 & 104.9 & 5 & 108.9 & 5 \\
\hline of which: Mortgages & 60.3 & 2 & 63.5 & 3 & 70.5 & 3 & 74.5 & 2 \\
\hline
\end{tabular}

Notes: The left-hand figures denote assets and liabilities outstanding at the end of the year as a percent of nominal disposable income, while the right-hand figures denote the rank of each country. Most figures are based on the UN System of National Accounts 1993 (SNA93) and, more specifically, for European Union countries, on the corresponding European System of Accounts 1995 (ESA95).

Households include non-profit institutions serving households. Net wealth is defined as nonfinancial and financial assets minus liabilities; net financial wealth is financial assets minus liabilities. Non-financial assets include stock of durable goods and dwellings, at replacement cost and at market value, respectively. Financial assets comprise currency and deposits, securities other than shares, loans, shares and other equity, insurance technical reserves; and other accounts receivable/payable. Not included are assets with regard to social security pension insurance schemes. Equities comprise shares and other equity, including quoted, unquoted and mutual fund shares. See also OECD Economic Outlook Sources and Methods (http://www.oecd.org/eco/sources-and-methods).

Primary sources: Banque de France, Flow of Funds Accounts. Germany: Deutsche Bundesbank, Monthly Report and Financial accounts for Germany 1991 to 1999, Special Statistical Publication, 2000. Italy: Banca d'Italia, Supplements to the Statistical Bulletin; Ando, A., L.Guiso, I.Visco (eds.), Saving and the Accumulation of Wealth, Cambridge University Press, 1994; OECD, Financial Accounts of OECD countries. Japan: Economic Planning Agency, Government of Japan, Annual Report on National Accounts. United Kingdom: Office for National Statistics, United Kingdom National Accounts, and Financial Statistics. United States: Federal Reserve Statistical Release, Flow of Funds Accounts of the United States.

Source: OECD Economic Outlook, vol. 2003/1, no. 73 (June 2003); vol. 2003/2, no. 74 (December 2003), Annex Table 56. 
Table 4: Share of Equities in Financial Assets and Share of Mortgages in Liabilities in the Group of Seven Countries, 1990-2001

\begin{tabular}{|c|c|c|c|c|c|c|c|c|}
\hline \multirow{2}{*}{$\begin{array}{l}\text { Country } \\
\text { Canada }\end{array}$} & \multirow[t]{2}{*}{1990} & \multicolumn{2}{|r|}{1995} & \multicolumn{2}{|r|}{2000} & \multicolumn{2}{|c|}{2001} & \\
\hline & & & & & & & & \\
\hline $\begin{array}{l}\text { Share of equities in } \\
\text { financial assets }\end{array}$ & 18.3 & 4 & 20.1 & 3 & 26.4 & 5 & 27.9 & $3 \mathrm{~T}$ \\
\hline $\begin{array}{l}\text { Share of mortgages in } \\
\text { liabilities }\end{array}$ & 63.7 & 5 & 66.6 & 4 & 61.8 & 6 & 60.7 & \\
\hline \multicolumn{9}{|l|}{ France } \\
\hline $\begin{array}{l}\text { Share of equities in } \\
\text { financial assets }\end{array}$ & 46.0 & 1 & 34.1 & 1 & 43.3 & 2 & 38.6 & 1 \\
\hline $\begin{array}{l}\text { Share of long-term loans in } \\
\text { liabilities }\end{array}$ & 67.9 & 4 & 75.9 & 1 & 72.1 & 3 & 68.1 & \\
\hline \multicolumn{9}{|l|}{ Germany } \\
\hline $\begin{array}{l}\text { Share of equities in } \\
\text { financial assets }\end{array}$ & 5.8 & 7 & 17.9 & 6 & 27.0 & 4 & 25.0 & 5 \\
\hline $\begin{array}{l}\text { Share of mortgages in } \\
\text { liabilities }\end{array}$ & 76.6 & 1 & 60.6 & 6 & 63.3 & 5 & 64.4 & 5 \\
\hline \multicolumn{9}{|l|}{ Italy } \\
\hline $\begin{array}{l}\text { Share of equities in } \\
\text { financial assets }\end{array}$ & 20.4 & 2 & 18.3 & 5 & 44.7 & 1 & 35.7 & 2 \\
\hline $\begin{array}{l}\text { Share of medium- and } \\
\text { long-term loans in }\end{array}$ & 47.1 & 6 & 60.7 & 5 & 72.8 & 1 & 73.7 & 1 \\
\hline \multicolumn{9}{|l|}{ Japan } \\
\hline $\begin{array}{l}\text { Share of equities in } \\
\text { financial assets }\end{array}$ & 14.4 & 6 & 10.8 & 7 & 9.0 & 7 & 7.1 & 7 \\
\hline $\begin{array}{l}\text { Share of mortgages in } \\
\text { liabilities }\end{array}$ & 38.7 & 7 & 42.7 & 7 & 44.4 & 7 & 44.6 & 7 \\
\hline \multicolumn{9}{|l|}{ United Kingdom } \\
\hline $\begin{array}{l}\text { Share of equities in } \\
\text { financial assets }\end{array}$ & 18.6 & 3 & 18.5 & 4 & 22.5 & 6 & 18.2 & 6 \\
\hline $\begin{array}{l}\text { Share of mortgages in } \\
\text { liabilities }\end{array}$ & 70.2 & 2 & 73.3 & 2 & 72.3 & 2 & 72.2 & 2 \\
\hline \multicolumn{9}{|l|}{ United States } \\
\hline $\begin{array}{l}\text { Share of equities in } \\
\text { financial assets }\end{array}$ & 15.1 & 5 & 24.5 & 2 & 31.1 & 3 & 27.9 & $3 \mathrm{~T}$ \\
\hline $\begin{array}{l}\text { Share of mortgages in } \\
\text { liabilities }\end{array}$ & 69.6 & 3 & 67.8 & 3 & 67.2 & 4 & 68.4 & 3 \\
\hline
\end{tabular}

Notes: The right-hand figures indicate the rank of each country.

Source: Table 3. 
Table 5: Consumption Levels in the Group of Seven Countries, 1970-2001

\begin{tabular}{|c|c|c|c|c|c|c|c|c|c|c|c|c|}
\hline Country & \multicolumn{2}{|c|}{1970} & \multicolumn{4}{|c|}{1985} & \multicolumn{3}{|c|}{2000} & \multicolumn{3}{|c|}{2001} \\
\hline Canada & 2,041 & 64.51 & 2 & 7,720 & 67.88 & 2 & 15,209 & 62.67 & 3 & 15,939 & 65.22 & 3 \\
\hline France & 1,943 & 61.41 & 3 & 7,183 & 63.16 & 3 & 13,392 & 55.19 & 7 & 14,245 & 58.29 & 7 \\
\hline Germany & 1,730 & 54.68 & 5 & 6,823 & 59.99 & 5 & 14,829 & 61.11 & 5 & 15,139 & 61.95 & 5 \\
\hline Japan & 1,405 & 44.41 & 7 & 6,640 & 58.38 & 6 & 14,248 & 58.71 & 6 & 14,569 & 59.62 & 6 \\
\hline United Kingdom & 1,908 & 60.30 & 4 & 6,637 & 58.36 & 7 & 15,944 & 65.70 & 2 & 16,745 & 68.52 & 2 \\
\hline United States & 3,164 & 100.00 & 1 & 11,373 & 100.00 & 1 & 24,267 & 100.00 & 1 & 24,438 & 100.00 & 1 \\
\hline OECD Mean & 1,935 & & & 7,155 & & & 15,234 & & & 15,656 & & \\
\hline
\end{tabular}

Notes: The left-hand figures show per capita household final consumption expenditure at current prices and current purchasing power parities (U.S. dollars), the middle figures show the ratio of the left-hand figure to the figure for the United States, and the right-hand figures show the rank of each country. The OECD means exclude the Czech Republic, Hungary, Poland, and the Slovak Republic.

Source: Organization for Economic Cooperation and Development, National Accounts of OECD Countries, Volume 1, 1990-2001: Main Aggregates (Paris: OECD, 2003), pp. 346-347. 
Table 6: Household Final Consumption Expenditure by Purpose for the Group of Seven Countries, 1990 and 2001

\begin{tabular}{|c|c|c|c|c|c|c|c|c|}
\hline Purpose of consumption & Canada & France & Germany & Italy & Japan & UK & US & G7 \\
\hline \multicolumn{9}{|l|}{1990} \\
\hline Food and non-alcoholic beverages & 10.93 & 14.95 & 12.94 & 18.25 & 16.46 & 11.41 & 8.48 & 13.35 \\
\hline Alcoholic beverages, tobacco and narcotics & 4.53 & 3.54 & 4.15 & 3.06 & 3.27 & 4.96 & 2.44 & 3.71 \\
\hline Housing, water, electricity, gas and other fuels & 24.86 & 22.48 & 22.12 & 18.87 & 21.62 & 18.68 & 18.47 & 21.01 \\
\hline \multicolumn{9}{|l|}{ Furnishings, household equipment and routine } \\
\hline Transport & 14.82 & 15.53 & 15.69 & 12.28 & 10.98 & 15.25 & 11.26 & 13.69 \\
\hline Communications & 1.66 & 1.57 & 1.67 & 1.54 & 1.13 & 1.59 & 1.61 & 1.54 \\
\hline Recreation and culture & 9.32 & 8.18 & 9.51 & 7.40 & 11.31 & 9.92 & 7.30 & 8.99 \\
\hline Education & 0.72 & 0.65 & 0.77 & 1.01 & 2.44 & 1.11 & 2.36 & 1.29 \\
\hline Restaurants and hotels & 8.22 & 7.78 & 5.81 & 8.60 & 6.38 & 12.56 & 6.57 & 7.99 \\
\hline Clothing and footwear & 5.73 & 5.06 & 6.67 & 9.49 & 5.06 & 7.31 & 6.03 & 6.48 \\
\hline Housing, water, electricity, gas and other fuels & 23.91 & 23.09 & 23.55 & 17.93 & 24.15 & 16.09 & 15.97 & 20.67 \\
\hline Furnishings, household equipment and routine & & & & & & & & \\
\hline maintenance of the house & 6.70 & 6.22 & 7.41 & 9.48 & 4.92 & 6.41 & 5.53 & 6.67 \\
\hline Health & 4.28 & 3.70 & 3.93 & 2.80 & 3.55 & 1.25 & 15.92 & 5.06 \\
\hline Transport & 14.63 & 14.84 & 13.90 & 12.36 & 10.32 & 14.39 & 11.28 & 13.10 \\
\hline Communications & 2.22 & 3.52 & 3.27 & 3.94 & 3.76 & 3.09 & 2.44 & 3.18 \\
\hline Recreation and culture & 11.27 & 9.61 & 9.77 & 8.19 & 12.43 & 14.93 & 10.59 & 10.97 \\
\hline Education & 1.14 & 0.61 & 0.65 & 0.98 & 1.94 & 1.19 & 2.15 & 1.24 \\
\hline Restaurants and hotels & 7.55 & 7.22 & 4.97 & 9.42 & 7.08 & 10.21 & 6.07 & 7.50 \\
\hline
\end{tabular}




\section{Table 6 (continued)}

Notes: The figures show consumption for each purpose as a share of the final consumption expenditure of households in the economic territory, both at 1995 prices. The figures for Germany are for 1991 instead of 1990 and for 2000 instead of 2001 because figures for 1990 and 2001 are not available, and the figures for the United States are for 2000 instead of 2001 because figures for 2001 are not available.

Sources: Organization for Economic Cooperation and Development, National Accounts of OECD Countries, Volume II, 1989-2001: Detailed Tables (Paris: OECD, 2002). The 2001 figures for Japan are from the same source as Figure 1. 


\section{Endnotes}

${ }^{1}$ In one government survey, 61.4 percent of the respondents agreed with the statement: "The Japanese are said to be frugal and saving-lovers, and I think this is a good thing." See Kenichi Tominaga and Takao Mamada, Nihonjin no Chochiku: Koudou to Ishiki (The Saving of the Japanese: Behavior and Attitudes) (Tokyo: Nihon Hyouronsha, 1995) (in Japanese).

${ }^{2}$ Charles Yuji Horioka, "Consuming and Saving," in Andrew Gordon, ed., Postwar Japan as History (Berkeley: University of California Press, 1993), 259-92.

3 The second major difference between the two series is that the series based on SNA68 includes payments in kind for medical and other services from social insurance (i.e., the portion of the cost of medical and other services covered by social insurance) in household disposable income and consumption whereas the series based on SNA93 does not. In order to make the two series as comparable as possible, the author added payments in kind for medical and other services from social insurance to household disposable income when computing the household saving rate from the data based on SNA93.

4 The discrepancy between the National Accounts data based on SNA93 and OECD data on Japan's household saving rate is due primarily to the treatment of payments in kind for medical and other services from social insurance (see footnote 3 above for details).

5 See, for example, Fumio Hayashi, “Why Is Japan's Saving Rate So Apparently High?” in Stanley Fischer, ed., NBER Macroeconomics Annual 1986, vol. 1 (Cambridge, Massachusetts: MIT Press, 1986), 147-210, and Charles Yuji Horioka, "Is Japan's Household Saving Rate Really High?" Review of Income and Wealth, series 41, no. 4 (December 1995):373-397. 
${ }^{6}$ Charles Yuji Horioka, "Why Is Japan's Household Saving Rate So High? A Literature Survey," Journal of the Japanese and International Economies 4, no. 1 (March 1990):49-92. See also Hayashi, “Why Is Japan’s Saving Rate So Apparently High?” 147-210.

${ }^{7}$ For an exposition of the life cycle hypothesis, see, for example, Franco Modigliani and Richard Brumberg, "Utility Analysis and the Consumption Function: An Interpretation of Cross-Section Data," in K. K. Kurihara, ed., Post-Keynesian Economics (New Brunswick, N.J.: Rutgers University Press), 388-436.

8 Sheldon Garon, Molding Japanese Minds: The State in Everyday Life (Princeton, N.J.: Princeton University Press, 1997).

${ }^{9}$ See Charles Yuji Horioka, "Future Trends in Japan's Saving Rate and the Implications Thereof for Japan's External Imbalance," Japan and the World Economy 3, no. 4 (April 1992):307-30, for a survey of the evidence. Also see Charles Yuji Horioka, "Saving in Japan," in Arnold Heertje, ed., World Savings: An International Survey (Oxford, UK: Blackwell Publishers, 1993), 238-78, and Charles Yuji Horioka, “Are the Japanese Selfish, Altruistic, or Dynastic?” Japanese Economic Review 53, no. 1 (March 2002):26-54, for evidence on whether the life cycle hypothesis applies in the case of Japan.

${ }^{10}$ Charles Yuji Horioka, "The Stagnation of Household Consumption in Japan," in Michael Hutchison and Frank Westermann, eds., Economic Stagnation in Japan (Cambridge, Massachusetts: MIT Press, forthcoming).

11 See Horioka, "Consuming and Saving," and Charles Yuji Horioka, "Japan's Consumption and Saving in International Perspective," Economic Development and Cultural Change 42, no. 2 
(January 1994):293-316, for data on more countries and over a longer time period.

${ }^{12}$ If market exchange rates are used to convert the figures for each country to U.S. dollars, consumption levels in Japan in 2001 were 73.5 percent of U.S. levels (as opposed to 59.6 percent when purchasing power parities are used to make the conversion), 118.5 percent of the G7 average (as opposed to 87.4 percent), and 125.0 percent of the OECD average (as opposed to 93.1 percent).

${ }^{13}$ Horioka, "Consuming and Saving," Tables 10-2 and 10-4.

${ }^{14}$ Note that the last two do not apply in present-day Japan. Eisuke Sakakibara and Robert A. Feldman, "The Japanese Financial System in Comparative Perspective," Journal of Comparative Economics 7, no. 1 (March 1983):1-24, discuss the differences in the financial market structures of Japan and the United States and argue that these differences (such as the far more intense competition for deposits among private financial institutions and the postal savings system in Japan) can help explain differences in household behavior. 